\title{
Effects of Teachers' Lecturing Style, Students' Seating Position and Students' Seating Preference on Recall
}

\author{
Dr. Ronald C.N. Oginyi ${ }^{1 *}$, Abojei Chris ${ }^{2}$, O, Ofoke S. Mbam³ ${ }^{3}$ Prof. B. O. Ehigie ${ }^{4}$, \\ Chia Francis Joseph ${ }^{5}$
}

\section{ABSTRACT}

In response to the decline of students' academic performance in non-western climes, this study investigated the effects of teachers' lecturing style (interactive and non-interactive lecturing style), students' seating position (front seat, middle seat and back seat) and students' seating preference (front seat, middle seat and back seat) on recall, using Secondary School students of a College in Ibadan. The study adopted a 2 x 3 x 3 Factorial between subjects design. Data was collected from one hundred and eight participants (108) who were selected randomly for the study and randomly assigned to groups. The result shows a significant difference in recall for lecturing style at $\mathrm{F}(1,90)=14.127 ; \mathrm{P}<.01$, (interactive lecturing style having a mean of 9.65 and the non-interactive lecturing style with a mean of 7.96). This shows that the interactive lecturing style has a more positive effect on recall. Students' seating position and seating preference shows no significant difference in recall at $\mathrm{F}(2,90)=1.981 ; \mathrm{P}>.05$ and $\mathrm{F}(2,90)=$ $0.000 ; \mathrm{P}>.05$ respectively. It was also found that there was no significant interaction effect of the three variables on recall at $\mathrm{F}(4,90)=1.138 ; \mathrm{P}>.05$. This study therefore recommends that teachers and instructors should employ an interactive lecturing style to help students have better recall and therefore perform better academically. Also further research should be carried out with a more representative sample in non-western climes.

Keywords: Teachers’ Lecturing Style, Students’ Seating Position, Students’ Seating Preference, Recall

\footnotetext{
${ }^{1}$ Ebonyi State University, Abakaliki

${ }^{2}$ Ebonyi State University, Abakaliki

${ }^{3}$ Ebonyi State University, Abakaliki

${ }^{4}$ University of Ibadan (UI), Ibadan

${ }^{5}$ National Drug Law Enforcement Agency (NDLEA) Nigeria

*Responding Author

(C) 2016 R Oginyi, A Chris, O Mbam, B Ehigie, C Joseph; licensee IJIP. This is an Open Access Research distributed under the terms of the Creative Commons Attribution License (http://creativecommons.org/licenses/by/2.0), which permits unrestricted use, distribution, and reproduction in any Medium, provided the original work is properly cited.
} 


\section{Effects of Teachers' Lecturing Style, Students' Seating Position and Students' Seating Preference on Recall}

One of the ways through which Psychologists measure and study memory processes of humans and animals as the case may require is by examining their ability to recall which is known as the retrieval of learned materials (Mulhall, 2011; Schacter, Gilbert, \& Wegner, 2011). The ability to retrieve learned material (Recall) is dependent on the ability to store the material (retention); which is the preservation of some aspects of experience across time (Walker \& Lambert, 1995). Recall therefore is an essential part of the study of memory and often comes into play in major memory researches; in fact, the greater part of experimental work on memory has been on recall (Mulhall 2011). In a classroom setting recall can be said to affect academic performance (Mlambo, 2011), in most cases the performance of students in their school work is highly dependent on their recall ability. Hence the association between recall and students' academic performance cannot be overly stressed. To this respect learning is ineffective if material learned cannot be recalled. Therefore the present study focuses on the effect of teachers' lecturing style, students' seating position and students' seating preference on recall.

According to the cognitive school, learning is seen as a seemingly permanent change in mental associations attributed to experience or change in how a person makes associations based upon experience (Mayer, 2003). Cognitively, the process of learning is examined by how an individual perceives, encodes, interprets, remembers, elaborates, and retrieves what they experience from memory (Moore, Burton, \& Myers, 1996). As individuals we are constantly bombarded with limitless bits of information that are recorded through our senses into our memory (Mayer \& Moreno, 2003). However, there is a limit to the amount of information that an individual can process in memory at a time (Baddeley, 1999; Moore, Burton \& Myers, 1996; Paivio, 1986). Information Processing theorists (Broadbent, 1958; Deutsch \& Deutsch, 1963) propose that the mind has a limited capacity for the amount and nature of the information it can process, and so just like a computer, the human mind processes information through the application of logical rules and strategies (Miller, 2011). It emphasizes the significance of "encoding" (input) of information, the "storage" of information, and the "retrieval" (access) of information. (Tan, 2003). This model explains that through the changes in the brain the individual's learning improves and these changes are most times spurred by the environment, which could include the source of information (the teacher), and the proximity of the individual to the source of the information (seating position). Recall in this case is enhanced by positive environmental structures.The Encoding Specificity theory provides a framework for understanding how contextual information affects memory and recall. The principle, proposed by researchers Thomson \& Tulving, (1973) states that memory is most effective when information available at encoding is also present at retrieval. Encoding begins at the perception of a stimulus and ends when such perception has been stored in the memory. Specifically, the encoding specificity principle stress that specific retrieval cues facilitate recall only when the information about them

and about their relation to the stimulus to be remembered is stored in the same memory web (Tulving, 1983). 


\section{Effects of Teachers' Lecturing Style, Students' Seating Position and Students' Seating Preference on Recall}

On the other hand motivational theories emphasize the place of an individual's drive as key to the recall of material. The Expectancy value theory (Vroom, 1964) propose that the degree to which an individual will expend effort on a task is a function of; their expectation that they will be able to perform the task successfully and by so doing obtain the rewards associated with a successful completion of the task and also that they value the rewards associated with successful completion of the task (Feather, 1969). The model assumes that the amount of effort invested is a product of the expectation of success and the value of the reward. Another motivational theory according to Bandura (1977, 1988) emphasize that Self-efficacy beliefs are important determinants of the amount of effort an individual would expand on a task. Individuals with high self-efficacy would continue with a task even if it is difficult while those with low self-efficacy will contribute minimum effort and, in many cases, give up easily. Bandura (1993) argues that stronger self-efficacy beliefs are associated with higher goals and firmer commitment to attaining the goals. Students with low efficacy are easily discouraged by failure and reduce their effort on tasks when confronted by difficult tasks. According to Bandura, people develop their personal sense of efficacy from four sources: performance accomplishment, observation of the performance of others, verbal persuasion and related types of social influence, and states of physiological arousal from which they judge personal capabilities and vulnerability (Bandura, 1982).

These theories all provide a framework for understanding recall, while cognitive theories focus on the processes of recall from encoding to storage and finally to retrieval of the encoded memory. Motivational theories emphasize the drive which students and teachers bring to the classroom. On the part of the motivational theories an individual's self-efficacy goes a long way to determine the individual's competence and performance. Students who believe in their ability to achieve do show better recall. Never-the-less the encoding specificity principle provides the best framework for understanding how contextual information affects memory and recall. Specific encoding operations determine what is to be stored, which in turn verifies which retrieval cues are effective in providing access to that which was stored. The theory places the teacher and the classroom arrangement as important factors that could affect the student's recall.

It is agreed that the teacher's positioning (lecturing style) impacts how students learn, receive information, and maintain on-task behaviour (Myers \& Anderson 2010). Lecturing style in this case refers to the way the teacher disseminates the content of the material either by actively interacting with the students or passively 'pouring' out course content. Two broad lecturing styles have been identified; the interactive and non-interactive lecturing style (Klavern, 2010; Aslam \& Kingdon, 2007; Ebert-May, Handelsman, Beichner, Bruns, Chang, DeHaan, Gentile, Lauffer, Stewart, Tilghman, \& Wood, 2004). Interactive lecturing involves an increased interchange between teachers, students and the lecture content. The use of interactive lectures can promote active learning, heighten attention and motivation, give feedback to the teacher and 


\section{Effects of Teachers' Lecturing Style, Students' Seating Position and Students' Seating Preference on Recall}

the student, and increase satisfaction for both (Steinert \& Snell 1999). The other style- the noninteractive style requires lectures to be recited without any significant interchange between the teacher, the student and the lecture content. These two styles compared are bound to produce different outcomes on the student in terms of encoding, recall and in turn performance.

Over time teachers who seek out ways to make lectures interactive (involving the active participation of the students) are believed to produce better students. It is observed that when the teacher is not engaged with the class, students are less motivated to learn and more tempted to participate in off task behaviour (Cruickshank, Jenkins \& Metcalf, 2009). Therefore if teachers are able to help their students maintain focus on the task and create effective communication they can also help the students create memory pathways for encoding the information. However, do teachers who practice the interactive lecturing style always have better results?

Firstly, Aslam \& Kingdon (2007) examined how student performance is influenced by several teacher activities and revealed that lesson planning, involving students by asking questions during class and quizzing them on past material all substantially benefit pupil learning. Research has demonstrated that students learn more when both teachers and students spend more time actively engaged in academic tasks (Brush, 1997). Overall, (Michel, Cater III \& Varela, 2010) found that, in general, it does not appear that the active learning approach is better than the passive learning when success is measured by broad cognitive outcomes. Studies by (Ebert-May \& Brewer, 1997; Ebert-May et. al. 2004) found that there were no significant differences in broad subject matter learning outcomes but rather a significant improvement in class-specific learning outcomes for students exposed to the active learning approach. Despite this findings a dilemma exist in that there seems to be no consistent definition for what an interactive lecturing style entails. Though most times it is agreed that certain traits like; engaging students in classroom activities, spending more time on task and constantly exposing students to interactive class quizzes, are commonly found with the interactive lecturing style. And generally these traits add up to what makes a lecturing style more productive and is therefore termed the interactive lecturing style which is contrary to the non-interactive lecturing style.

Students' Seating Position is another factor predicted to affect recall and in turn students' academic performance. It refers to the way students' seats are arranged in order of front roll seats, middle roll seats and back roll seats and what seats these students actually sit in. The seating arrangement of the classroom determines what position is defined as; front roll seats, middle roll seats, and back roll seats. Therefore the seats are judged by their distance from the instructor: front roll seats represent the seats closest to the instructor, while the back roll seats represent the seats farthest from the instructor and the middle roll seats are the seats of average distance from the instructor. Before now the effect of seat location on learning had received surprisingly little attention in education literature (Weinstein 1979). Educators probably did not 


\section{Effects of Teachers' Lecturing Style, Students' Seating Position and Students' Seating Preference on Recall}

consider seating location as a variable strong enough to affect students' performance. But with recent studies on classroom environment and its effect on performance seating position has slowly made its way to becoming a major focus. The questions researchers ask is, does the position which students sit in class affect their performance?

Griffith (1921) published one of the first reports on this subject and noted that students sitting at the last row had low academic performance; he claimed that the front and center seats of the room were the best places to perform well. Later, other studies documented that students who sit near the blackboard usually have a better school performance (Sommer, 1967; Schwebel \& Cherlin, 1972; Becker et al., 1973, Levine et al., 1980; Holliman \& Anderson, 1986; Pedersen, 1994; Benedict \& Hoag, 2004; Perkins \& Wieman, 2005).Both Holliman \& Anderson (1986) and Becker et al. (1976) found that as the distance from the instructor to the student seat increased, student performance decreased. Despite these findings the effect of randomly assigned seating on student performance is unclear. One study by Kalinowski \& Taper (2007) found no relationship between random seat assignments and student outcomes. This contrasts with the results (Sommer, 1967; Schwebel \& Cherlin, 1972; Becker et al., 1973, Levine et al., 1980; Holliman \& Anderson, 1986; Pedersen, 1994; Benedict \& Hoag, 2004; Perkins \& Wieman, 2005). They obtained two noteworthy results. First, they found no evidence that grades or student attitudes were affected by seat location. Nor was there a suggestion of any such relationship. In a comparison study of self-selection and assigned seating, Stires (1980) found no grade differences between students who chose to sit at the front of the class versus students assigned to sit up close. Meeks, Knotts, James, Williams, Vassar \& Wren (2013) also confirmed the result of Kalinowski \& Taper in a study of the impact of seating location and seating type on student performance. The findings suggest that student performance is not significantly altered by seating location or seating type. Therefore literature regarding the effect of seating location on performance is mixed.

In some settings however, students are allocated to their various sitting positions and in other conditions students get to choose the seats they sit in. It has been noted that individual difference exists in their preferences: some students prefer to sit in the front, while others prefer to sit at the back or middle seat; this is referred to as the students' preferred seating position. In cases where students are given the opportunity to choose their seats, the seats they choose may depend on other factors best known to the student and this chose might also affect the students' recall. It is observed that students who prefer to sit in front seats perform better on an average than those who sit at the back. Having examined the effect of students' seating position on performance; another variable that is of interest in this research is students' seating preference. In a slightly recent study on seating location in large lectures (Benedict \& Hoag, 2004) asked the following question: are Seating Preferences or Location Related to Course Performance? They reported that individuals who prefer to sit near the front of the room have a higher probability of receiving

(C) The International Journal of Indian Psychology, ISSN 2348-5396 (e)| ISSN: 2349-3429 (p) | 14 


\section{Effects of Teachers' Lecturing Style, Students' Seating Position and Students' Seating Preference on Recall}

high grades, where-as students which prefer the back have a higher probability of receiving poorer grades. A preference for sitting in the back, regardless whether one did so, increased the probability of receiving poor grades by 23 percentage points. Students unable to sit in their preferred locations and forced forward tend to receive higher grades, despite their preferences for back seats. Seating preferences and final seat location therefore may be separate factors affecting grade performance.

According to Vander Schee (2011), seat selection has no significant correlation with student GPA; however, students who preferred to sit in the front row did outperform others in the class in terms of overall course grade. Earlier work by Wulf (1977) showed that while students who chose their seats in the front of the classroom outperformed others in the class, randomly assigned seats yielded no significant difference in performance relative to seat location. Overall, the literature reveals a weak inverse relationship between student performance and distance from the instructor. In their study of seat choice and personality, Totusek \& Staton-Spicer (1982) tested two hypotheses: students who choose to sit in the front or at the center have different personality traits than students sitting else-where. Totusek \& Staton-Spicer concluded that there are personality differences among students based on seat location especially when the seat is the students' preference, and that the seat location creates some personality traits in students.

In summary the position which a student prefers to sits tells a lot about their personality, and indirectly their academic potentials. In exam conditions teachers can predict which students are likely to cheat in the exam hall just by observing the seats which the students prefer to sit in. Also predictions have been made that students positioning can affect how they focus on information, encode information and invariably how they recall information. Despite these predictions researches focus less on the effect of students' seating position and students' seating preference on recall. The focus in most research has been mostly on seating arrangement and its effect on general performance which differs significantly from the students' actual seating position.

In a society such as ours where formal education seems to be the most 'colourful' path way to success, even more emphasis should be placed on the topic of recall which is mostly judged by the students' academic performance. Since few studies have been carried out on the effect of lecturing style, seating position, seating preference on recall especially in non-western climes, the purpose of the study was to investigate the effect of lecturing style, seating position, seating preference on recall. It hopes to discover whether students' ability to recall lecture information can be attributed to their sitting position, preference or the lecturing style employed by the teacher. 


\section{Effects of Teachers' Lecturing Style, Students' Seating Position and Students' Seating Preference on Recall}

The following hypotheses were stated in the study:

- Participants exposed to the interactive lecturing style would score significantly higher on recall than those exposed to the non-interactive lecturing style.

- Students' seating position would significantly affect recall.

- Students' seating preference would significantly affect recall.

\section{METHODS}

\section{Participants}

The sample consisted of male and female students at senior secondary school level. A total of one hundred and eight students (108) participated in the research. The sample was selected from students of Immanuel College Agbowo, Ibadan, Oyo State, Nigeria. To avoid the effect of confounding variables such as sex, the sample was evenly distributed with 54 males (50\%) and 54 females (50\%) with a mean age of 16.5 years and an SD of 2.34 .

\section{Instruments}

Demographic Information: This section is designed to get information in the area of demographic characteristics of the participants: it contains three items the student's Name, Gender, Age and Preferred Seating Position.

Recall Test: A recall test was developed and standardized for the purpose of this study. The test was designed to test students' recall ability. It contains a comprehension passage adopted from Frederic Bartlett's “The war of the Ghosts” which is an English translation of a Native American folk story. This story was also used by Bartlett (1932) in one of his famous memory experiments where his subjects were required to recall the story in as much details as possible at various time intervals after the story was originally presented to them. Followed by the comprehension are 13 items based on the comprehension to ascertain students' level of recall, the test is supposed to be taken within 20mins. The test has a Kuder Richardson reliability of 0.83 and overall mean of 8.63 and an SD of 3.23. In addition to having content validity a face validity of $82.22 \%$ was also obtained for the test.

\section{Recall Test Standardization Procedure}

Validity: The test was validated by five (5) experts in English Language and Communication Arts with a minimum qualification of M.A. or M.ed. The experts were selected from three secondary schools in Ibadan north Local Government Area of Oyo State Nigeria. The experts made adjustments to the adopted comprehension to fit the population in question; they also helped in developing the items for the test. Face validity was done on the entire test; sixty (60) senior secondary school students were asked to rate the test YES if they understood the test content (the comprehension passage and items) and NO if they did not understand the test contents. 82.22\% of the students rated the test YES meaning they understood the tests contents. Reliability: In this study, using a standardization sample of 60 participants, a strong reliability measure was obtained. Item analysis was also done using a Point Biserial Correlation. An initial 


\section{Effects of Teachers' Lecturing Style, Students' Seating Position and Students' Seating Preference on Recall}

14 items were developed, these items were later reduced to 13 items after conducting a point biserial correlation and it was found that one of the 14 items did not meet up to a correlation of 0.25 , having a value of 0.022 . The item with the highest value, item 13 was found to be 0.712 , while the item with the lowest value, item 9 was found to be 0.261 giving a range of 0.451 , hence all the items on the test were found to be valid.

\section{Procedure}

The researcher made use of a random sampling method and random assignment technique. Students at the senior secondary level of Immanuel College were approached to volunteer for the study, out of which a total of 193 students (92 males and 101 females) indicated their interest in being part of the study. The volunteers were asked to indicate their seat preference, whether they would like to sit at the front, middle or back seat as they volunteered; for the male volunteers, 29 indicated the front seat as their seat preference while 38 picked the middle seat and 25 students indicated the back seat as their preferred seat. And for the females 43 picked the front seat, while 38 picked the middle seat and 20 students indicated the back seat as their preferred seat. Out of this number, 36 participants (18 males and 18 females) each from the three seat preference (the front seat, middle seat and back seat preference) were picked by balloting making a total of 108 participants (54 males and 54 females).

The 54 male participants (18 participants each, with front seat preference, middle seat preference and back seat preference respectively) were then divided into their respective seating position. The 18 male participants who chose the front seat were divided randomly (3 cells with 6 participants each) into the front seat position, middle seat position and back seat position. The same procedure was done for the other seat preferences (middle seat and back seat preference). Participants in each of the assigned seating positions were then divided into two equal groups, labelled group B1 and B2 respectively. This amounted to a total 9 cells with 3 male participants each in the respective groups. In total 27 male participants each were assigned to the two groups. By random assignment, specifically by the use of balloting these participants were then exposed to the lecturing treatment.

The same procedure was used for the female participants. The male and female participants in the two groups B1 and B2 were then merged together. Each group had a total number of 54 participants each representing 27 males and 27 females. The subgroups are arranged as illustrated in table 1. After the selection and assignment, participants in B1 were exposed to the interactive lecturing style while participants in B2 were exposed to the non-interactive lecturing style. The students were then given a test on the lecture content (i.e. the recall test). Students'

performances were then assessed, and the dependent variable was measured based on the students' performances on the test. The data was then analyzed and the result presented. 


\section{Effects of Teachers' Lecturing Style, Students' Seating Position and Students' Seating Preference on Recall}

\section{Design/Statistics}

A $2 \times 3 \times 3$ Factorial design was used in designing the research. Teachers' lecturing teaching style was manipulated on two levels: interactive and non-interactive lecturing style. Students' seating position was manipulated on three levels: front roll seats, middle roll seats, and back roll seats. Likewise students' seating preference was manipulated on three levels: front roll seats, middle roll seats, and back roll seat. The research design is illustrated in table 1. Data collected in the study were analyzed using Statistical Package for Social Science (SPSS) software version 20.0. Both descriptive and inferential statistics were used in the analysis of the data collected. Specifically, a 2 x 3 x 3 Analysis of Variance (ANOVA) was used test all the stated hypotheses.

\section{RESULTS}

Table 2 shows the result of the analysis.

Table 2: 2 × 3 × 3 ANOVA Summary of Participants' Recall

$\begin{array}{llllll}\text { Source } & \text { Sum of Squares } & & \text { df } & \text { Mean square } & \text { F Sig. } \\ \text { Lecturing Style (A) } & 76.676 & 1 & 76.676 & 14.127 & .000 \\ \text { Students Seating Position (B) } & 21.500 & 2 & 10.750 & 1.981 & .144 \\ \text { Students Seating Preference (C) } & .000 & 2 & .000 & .000 & 1.000 \\ \text { A x B } & 13.685 & 2 & 6.843 & 1.261 & .288 \\ \text { A x C } & 3.185 & 2 & 1.593 & .293 & .746 \\ \text { B x C } & 20.667 & 4 & 5.167 & .952 & .438 \\ \text { A x B x C } & 24.704 & 4 & 6.176 & 1.138 & .344 \\ \text { Error } & 488.500 & 90 & 5.428 & & \\ \text { Total } & 9023.000 & 108 & & & \end{array}$

The result of the 3-way analysis of variance (ANOVA) show that the main effect of lecturing style on recall was significant $\mathrm{F}(1,90)=14.127 ; \mathrm{P}<.01$. While students' seating position and students' seating preference showed no significant effect on recall. Also there was no interaction effect between the variables on recall.

The first hypothesis which stated that participants exposed to the interactive lecturing style would score significantly higher on recall than those exposed to the non-interactive lecturing style was tested using 2 x 3 × 3 ANOVA and the result is presented in tables 2 and 3.

Table 3: Summary of the mean distribution for the effect of teachers' lecturing style (interactive and non-interactive lecturing style) on recall

$\begin{array}{llcc}\text { Lecturing style } & \mathbf{N} & \bar{X} & \text { SD } \\ \text { Interactive } & 54 & 9.65 & 2.085 \\ \text { Non-interactive } & 54 & 7.96 & 2.540\end{array}$

(c) The International Journal of Indian Psychology, ISSN 2348-5396 (e)| ISSN: 2349-3429 (p) | 18 


\section{Effects of Teachers' Lecturing Style, Students' Seating Position and Students' Seating Preference on Recall}

It was presented that participants exposed to the interactive lecturing style $(\bar{X}=9.65$ ) scored significantly higher than those exposed to the non-interactive lecturing style $(\bar{X}=7.96)$ at $\mathrm{F}$ (1, $90)=14.127 ; \mathrm{P}<.01$. This result confirms the stated hypothesis.

\section{DISCUSSION}

The current study investigated the effect of teachers' lecturing style, students' seating position and students' seating preference on recall. For this purpose three hypotheses were tested. The first hypothesis stated that participants exposed to the interactive lecturing style would score significantly higher on recall than those exposed to the non-interactive lecturing style. The result of the test confirmed the stated hypothesis. It thus suggests that there is a significant difference in the recall between students exposed to the interactive lecture style and the non-interactive lecture style. This study was confirmed by (Steinert \& Snell 1999; Aslam \& Kingdon 2007).

The second hypothesis stated that Students' seating position would significantly affect recall. Findings reveal that the hypothesis was unverified. It thus suggests that regardless of where students sit in class their recall is not affected. Although the result was not as the hypothesis stated, this finding is supported by (Stires, 1980; Kalinowski \& Taper 2007; Meeks, Knotts, James, Williams, Vassar \& Wren 2013) who found no relationship between random seat assignments and student outcomes. However these findings do not correlate with some other studies on the same subject. It is reported that students who sit near the blackboard usually have a better school performance (Becker et al., 1973, Levine et al., 1980; Holliman \& Anderson, 1986; Pedersen, 1994; Benedict \& Hoag, 2004; Perkins \& Wieman, 2005; Stires, 1980; Sommer, 1967; Schwebel \& Cherlin, 1972). Despite this contradiction the result shows some level of consistency with recent studies and adds to the existing knowledge.

The third hypothesis stated that students' seating preference would significantly affect recall. Again findings reveal that the hypothesis was also unverified. It was presented that there was no significant effect of students' seating preference on recall. This result is therefore in line with the findings of Vander Schee (2011), which reports that students seat selection had no significant correlation with student overall performance.

\section{CONCLUSION}

In conclusion, it was revealed that only the teachers' lecturing style had an effect on recall. Those exposed to the interactive lecturing style scored higher than those exposed to the noninteractive lecturing style. This finding places the lecturing style employed by teachers as a very important variable when students' recall and academic performance is concerned. As explained by cognitive theories, it is seen that the teacher affects the information processing of the student, in encoding, storage and recall. The teacher also has the power to influence students' motivation 


\section{Effects of Teachers' Lecturing Style, Students' Seating Position and Students' Seating Preference on Recall}

as well, by helping the student create an expectation towards learning as explained by the expectancy theory and can also help the student build self-efficacy.

The impact of seating on recall when compared to existing studies, presents a contradictory result: while recent literatures show no significant effect of seating on recall, older literatures seem to contradict these findings. This study seems to agree with the recent findings on the effect of seating on recall. It can be said that students' motives for choosing a particular seat over another have changed overtime. In this study for example, when the students were asked why they sat in their respective seats, they reported such reasons as: having eye defects and height advantages or disadvantage as the case may be. This clearly shows that seating is more influenced by other factors that do not correlate and might not contribute to a students' ability to recall. Therefore we agree that seating position and preference are not significant variables that affect a students' recall.

\section{IMPLICATION OF THE STUDY}

Although it will be too early to conclude, the results obtained in this study indicate that the ability to recall specific information after being exposed to a stimulus lies majorly on the messenger and his/her mode of delivering the message. It might be safe then to imply that the teachers' lecturing style is the most significant variable that affects students' recall, and that the location of the student does not really count. The interest of the students in the class activities, their motivation and invariable the students recall lies to a great deal on the teacher's ability to interact the course material effectively with the students and just as an ancient Chinese proverb puts it "there are no bad students only bad teachers".

Consequently, considering the rapid decline in education in Nigeria, this study has excelled in shedding more light and providing insight into how much impact the teachers' style of lecturing contributes to the decline of education in the country. Hopefully, information gotten from the study would help mortify this challenge. It is therefore recommended that policy makers and educators should invest more in training of teachers on the use the interactive lecturing style in teaching, and also develop more applicable teaching policies, laws and practices and emphasize strictly that the teachers abide by them.

\section{LIMITATIONS AND RECOMMENDATIONS FOR FURTHER STUDIES}

Although, the present study has made important contribution to the body of knowledge, taking the study of recall a step further by examining teachers' lecturing style, students' seating position and students' preference as factors that could affect recall. Nevertheless the study is not without its own limitations. One limitation this study has is in the sample size used; 108 secondary school students of Immanuel College Agbowo, Ibadan. This sample size cannot be said to be a proper representation of the general population, hence, might not allow adequate generalization.

(C) The International Journal of Indian Psychology, ISSN 2348-5396 (e)| ISSN: 2349-3429 (p) | 20 


\section{Effects of Teachers' Lecturing Style, Students' Seating Position and Students' Seating Preference on Recall}

A second limitation encountered by the researcher in the course of this study is the dearth of empirical studies to support the research. There are lots of gaps yet to be filled. Most of the research work done has been mostly on seating arrangement and location. There were few empirical studies found on seating preference and lecturing style as defined by the researcher. Again most of the empirical studies focused on student performance and very few on recall. The time frame of research was also noted as a major limitation of the study. Therefore it might not be accurate to assume that the differences noted in the study for lecturing style would be the same in a more longitudinal research, where lectures are carried out over a longer period.

For further studies, it is recommended that studies should be carried out in this area involving a more representative sample over a more longitudinal frame. This will go a long way to ascertain the validity and reliability of the findings of this study. Also more researchers should be encouraged to develop interest in this field especially in non-western climes in order to validate the claims in other cultures.

\section{Acknowledgments}

The author appreciates all those who participated in the study and helped to facilitate the research process.

\section{Conflict of Interests}

The author declared no conflict of interests.

\section{REFERENCES}

Annabelle Myers and Sofia Anderson, (2010). e How Teacher Positioning in the Classroom Affects the On-Task Behavior of Students -Journal of Student Research, 2, Spring 2010.

Atkinson, R.C \& Shiffrin, R.M. (1971) "The Control of Short Term Memory" Scientific American 225, (82-90), Retrieved from http://suppes-corpus.stanford.edu/techreports/IMSSS_173.pdf

Bandura, A. (1977). Self-efficacy: Toward a unifying theory of behavioral change. Psychological Review.84: 191-215.

Bandura, A. (1988). Self-regulation of motivation and action through goal systems. In Hamilton, V., Bower, G. H., and Frijda, N. H. (eds.), Cognitive Perspectives on Emotion and Motivation, Kluwer, Dordrecht, the Netherlands, pp. 37-61.

Bartlett, F.C. (1932). Remembering: A study in experimental and Social Psychology. Cambridge University Press. Retrieved from http://ematusov.soe.udel.edu/EDUC390.demo/Articles/The\%20war\%20of\%20the\%20gh osts.htm . 


\section{Effects of Teachers' Lecturing Style, Students' Seating Position and Students' Seating Preference on Recall}

Benedict, M.E., and J. Hoag. (2004). Seating location in large lectures: Are seating preferences or location related to course performance? Journal of Economic Education,35 (3), 21531.

Bligh, D. A. (2000). What's the use of lectures? San Francisco: Jossey-Bass.

Botvinick, M.; Wang, J.; Cowan, E.; Roy, S.; Bastianen, C.; Mayo, P.J.; Houk, J.C. (2009). "An analysis of immediate serial recall performance in a macaque". Animal Cognition 12: 671-678. doi :10.1007/ s10071-009-0226-z .

Bower, Gordon H. (2000). A Brief History of Memory Research. The Oxford Handbook of Memory.

Broadbent, D. (1958). Perception and communication. London: Pergamon Press.

Brush, T. (1997). The Effects of Group Composition on Achievement and Time on Task for Students Completing ILS Activities in Cooperative Pairs. Journal of Research on Computing in Education, 30, 2-17.

Butler, R. (1989). Mastery versus ability appraisal: A developmental study of children's observations of peers' work. Child Develop,60, 934-943.

Butler, R. (1999). Information seeking and achievement motivation in middle childhood and adolescence: The role of conceptions of ability. Developmental Psychology35: 146-163.

Chris van Klaveren. (2010). Lecturing style teaching and student performance. University of Maastricht, TIER, Faculty of Economics and Business, Netherlands.

Cruickshank D.R., Jenkins D.B., \& Metcalf K.K. (2009). The Act of Teaching.5th Edition. Boston: McGraw Hill.

D. Ebert-May, Handelsman, J., R. Beichner, P. Bruns, A. Chang, R. DeHaan, J. Gentile, S. Lauffer, J. Stewart, S.M. Tilghman, and W.B. Wood. (2004). Scientific teaching. Science, 304 (5670), 521-22.

Deutsch, J. A., \& Deutsch, D. (1963). Attention: Some Theoretical Considerations. Psychological Review, 70, 80-90

Ebbinghaus, Hermann. (1885). On Memory (H.A Ruger \& C.E Bussenius, Trans.) New York: Dover, 1964.

Ebert-May, D., and C. Brewer. (1997). Innovative in large lectures-teaching for active learning. Bioscience, 47 (9), 601-08.

Endel Tulving. (1972). "Episodic and Semantic Memory" in Organization of memory, (381403), Retrieved from http://alicekim.ca/ EMSM72.pdf .

Feather, N. T. (1969).Attribution of responsibility and valence of success and failure in relation to initial confidence and task performance. Journal of Personal Social Psychology,13, 129-144.

Griffith CR (1921).A comment uppon the psychology of audience. Psychology Monogram, 30, 36-47.

Holliman WB, Anderson HN (1986). Proximity and student density as ecological variables in a college classroom. Teaching Psychology, 13, 200- 203. 


\section{Effects of Teachers' Lecturing Style, Students' Seating Position and Students' Seating Preference on Recall}

Kalinowski S, Taper ML (2007). The effect of seat location on exam grades and student perceptions in an introductory biology class.Journal of College Science Teaching, 36, 5457.

L. Schacter, Daniel T. Gilbert, and Daniel M. Wegner, (2011). Retrieval: Bringing Memories to Mind. 2nd ed. New York: Worth Publishers, 2011. 232-235. Print.

M. Aslam and G. Kingdom. (2007). What can teachers do to raise pupil achievement: working paper series, The center for the study of African economics.

Michael D. Meeks, Tami L. Knotts, Karen D. James, Felice Williams, John A. Vassar and Amy Oakes Wren. (2013). The Impact of Seating Location and Seating Type on Student Performance. Education Science, 3, 375-386; doi:10.3390/educsci3040375

Miller, G.A. (2003). The cognitive revolution: a historical perspective. Trends in Cognitive Science, 7, 141-145

Mulhall, E. F. (2011). Experimental studies in recall and recognition. American Journal of Psychology. 26(2), 217-228.

Newell, Allen \& Simon, Herbert. (1961). Computer simulation of human thinking. Science , 134, (2011-2017), Retrieved from http://psycnet.apa.org/? fa=main.doiLanding\&uid=196205907-001

Paivio, Allan. (1969). Mental Imagery in Associative Learning and Memory. Psychological Review 76, (241-263), Retrieved from http://psycnet.apa.org/journals/rev/76/3/241/ .

Perkins KK, Wieman C (2005). The surprising impact of seat location on student performance. The Physic .Journal College Science Teaching, 43, 30-33.

Pintrich, P. R., and DeGroot, E. V. (1990).Motivational and self-regulated learning components of classroom academic performance. Journal of Educational Psychology,82, 33-40.

Rock, Irvin; Walter Helmer (1959). "Further Evidence of One Trial Associative Learning". The American Journal of Psychology (University of Illinois Press).

Sommer R (1967). Classroom ecology. Journal of Applied Behaviour Science, 3, 489-503.

Stires L (1980). Classroom seating location, student grades, and attitudes: Environment or selfselection. Environmental Behaviour, 12, 241-254.

Tan Oon Seng, Richard D. Parson, Stephanie lewis Hinson, Deborah Sardo-Brown (2003). Educational Psychology. Singapore : Thomson Learning.

Totusek P, Staton-Spicer A (1982).Classroom seating preference as a function of student personality. Journal of Experimental Education, 505, 159-163.

Tulving, E.; Thomson, M. (1973). "Encoding specificity and retrieval processes in episodic memory". Psychological Review 80 (5): 352-373. doi : 10.1037/h0020071.

Vander Schee, B. A. (2011) Marketing classroom spaces: Is it really better at front? Management Education Review. 2011. 21, 201-210

Victor Mlambo, (2011). An analysis of some factors affecting student academic performance in introductory biochemistry course at the University of the West Indies. Caribbean Teaching Scholar, 1, (20), 79-92. 


\section{Effects of Teachers' Lecturing Style, Students' Seating Position and Students' Seating Preference on Recall}

Vroom, V. H. (1964). Work and Motivation. New York: Mcgraw Hill.

Walker, D., \& Lambert, L. (1995). Learning and leading theory: A century in the making. In L. Lambert et al., The constructivist leader (pp. 1-27). New York: Teachers College Press.

Watkins, M.; Gardiner, J. M. (1979). "An appreciation of the generate-recognize theory of recall". Journal of Verbal Learning and Verbal Behavior 18 : 687-704. doi :10.1016/s0022-5371(79)90397-9 .

Weiner, B. (1994). Integrating social and personal theories of achievement striving. Rev. Educat. Res. 64: 557-573.

Weinstein, C.S. (1979). The physical environment of the school: A review of the research. Review of Educational Research,49 (4), 577-610.

Wolford, George (1971). "Function of Distinct Associations for Paired- Associate Performance". American Psychology Association .

Wulf, K. (1977). Relationship of assigned classroom seating area to achievement variables. Education Research Quarter, 2, 56-62

How to cite this article: Oginyi, A Chris, O Mbam, B Ehigie, C Joseph (2016), Effects of Teachers' Lecturing Style, Students' Seating Position and Students' Seating Preference on Recall, International Journal of Indian Psychology, Volume 4, Issue 1, No. 79, ISSN:2348-5396 (e), ISSN:2349-3429 (p), DIP:18.01.082/20160304, ISBN:978-1-365-56745-2 